
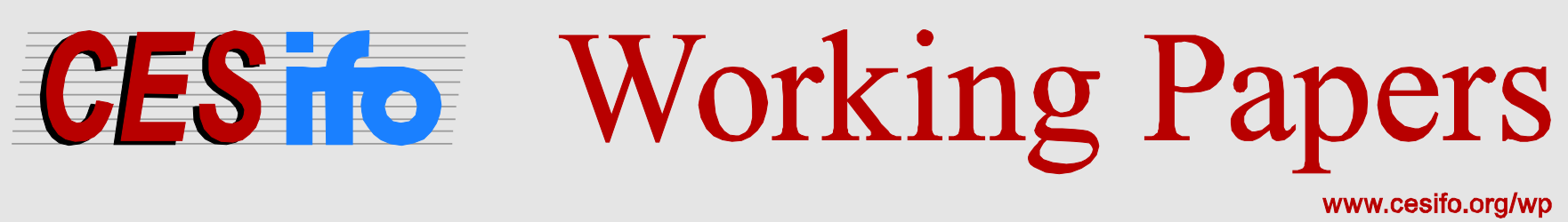

\title{
Digital Tools and the Derailment of Iceland's New Constitution
}

\author{
Thorvaldur Gylfason \\ Anne Meuwese
}

CESIFO WORKING PAPER NO. 5997

CATEgory 2: Public CHOICE

JULY 2016

An electronic version of the paper may be downloaded

- from the SSRN website:

- from the RePEc website:

- from the CESifo website: WWw.SSRN.com

www.RePEc.org

www.CESifo-group.org/wp

ISSN 2364-1428 


\title{
Digital Tools and the Derailment of Iceland's New Constitution
}

\begin{abstract}
This paper maps the use of digital tools in the Icelandic constitutional revision process of 2011 and discusses its aftermath in subsequent years. Although causal links between the digital elements of the process and the content and fate of the constitutional bill are impossible to establish, an analysis of the Icelandic constitution-writing efforts as 'digital democracy' reveals some important lessons. High-quality input into constitution-making processes through digital participation is possible, but the very threat of this to vested institutional interests also makes consensus on and enforcement of the 'rules of the game' of paramount importance.
\end{abstract}

JEL-Codes: K100.

Keywords: digital tools, democracy, constitutions, Iceland.

\author{
Thorvaldur Gylfason \\ University of Iceland \\ Department of Economics \\ Scemundargata 2 \\ Iceland - 101 Reykjavik \\ gylfason@hi.is
}

\author{
Anne Meuwese \\ Tilburg University \\ Tilburg Law School \\ Warandelaan 2 \\ The Netherlands - 5037 AB, Tilburg \\ Anne.Meuwese@uvt.nl
}

The authors wish to thank Arnfríður Guðmundsdóttir, Thorkell Helgason, Hjörtur Hjartarson, Finnur P. Magnússon, Sigríður Ólafsdóttir, and an anonymous referee for helpful comments on an earlier version of the text. They are grateful also to Simone Gooijaers for her research assistance. 


\section{Introduction}

One way to view the constitutional revision process, set in motion in the wake of the 2009 'Pots and Pans Revolution', triggered by the financial crisis in Iceland, is to see it as an experiment in democracy, 'digital democracy' in particular. From a broader perspective, the Icelandic process, which has drawn considerable academic attention, ${ }^{1}$ is not the first example of popular involvement in constitution-making, but it is probably the most deliberate, the most democratic, and the most 'global' one to date. The drafting process was special both in terms of the extent of public participation and the way it was facilitated by digital means. We do not yet know how the story will end. The bill was approved by 67 per cent of the voters in a national referendum called by parliament in 2012, but the same parliament failed to ratify it before adjourning in 2013, leaving the bill in suspension where it remains at the time of writing (June 2016).

This chapter has a twofold aim: introducing the Icelandic constitution-writing efforts generally and reporting on the extensive use of digital tools more specifically. The latter has been hailed as 'the most celebrated aspect of the Icelandic constitutional drafting process among advocates of "open government" worldwide'2 . In constitution-drafting processes we can distinguish several phases, each of which can involve public participation by digital means: the 'constitutional moment' that was the trigger for revising the constitution; the election of the constituent assembly; the drafting of the constitutional text; and its adoption. ${ }^{3}$ In the Icelandic case, the public participated in both the election of a Constitutional Council, tasked with drafting a new constitution, and - with the assistance of various digital tools - the drafting process itself. This chapter emphasizes the latter stage because this is where the link with the theme of the volume, e-Democracy, is strongest. ${ }^{4}$

Since it is important for a rich understanding of the use of digital tools, including their limitations, to have some context, ${ }^{5}$ this chapter will offer a brief description of the process in

\footnotetext{
${ }^{1}$ M Tushnet, 'New Institutional Mechanisms for Making Constitutional Law' (2015), $<$ http://papers.ssrn.com/sol3/papers.cfm?abstract_id=2589178> accessed 24 January 2016.

2 ACM Meuwese, 'Popular constitution-making. The case of Iceland', in D Galligan and M Versteeg (eds.), The social and political foundations of constitutions (Cambridge University Press 2013).

${ }^{3}$ C Klein and A Sajó, 'Constitution-Making: Process and Substance' in M Rosenfeld and A Sajó (eds.), Oxford Handbook of Comparative Constitutional Law (Oxford University Press 2012), 425; J Widner, Proceedings 'Workshop on Constitution Building Processes', (2007) Princeton University, May 17-20 Princeton, NJ: Bobst Center for Peace and Justice, Princeton University, Interpeace International IDEA.

${ }^{4}$ For more details on the participatory elements in the election and the referendum that was held after the Constitutional Council delivered its bill to parliament, see Meuwese (2013) and Gylfason (2013, 2014).

${ }^{5}$ For more extensive descriptions, see T Gylfason, 'Constitutions: Financial Crisis Can Lead to Change' (2012) 55(5) Challenge 1; T Gylfason, 'From Collapse to Constitution: The Case of Iceland', in L Paganetto (ed.), Public Debt, Global Governance and Economic Dynamism (Springer 2013) ; T Gylfason, 'Constitution on Ice', (2014a) CESifo Working Paper No. 5056, forthcoming in Ingimundarson et al. (eds.), Iceland's Financial
} 
its entirety (Section II). Section III presents an inventory of digital aspects of the Icelandic experiment, discussing the role of digitalization in four important features of the case: the uniquely shaped drafting process, the fact that participation was not limited to Icelandic citizens, the content of the constitutional bill, and the treatment of the bill by parliament. Our analysis will be guided by insights from the specialized literature on 'popular constitutionmaking' dealing with a range of possible effects of public participation in constitutionmaking. ${ }^{6}$ Section IV concludes.

\section{An overview of the constitution-making process}

As a severe financial crisis brought to light a lingering dissatisfaction with Iceland's clientelistic political culture, ${ }^{7}$ a fundamental constitutional revision - long overdue - came within reach in 2008-2009. It was long overdue because the constitution from 1944, dating from 1874 , or rather $1849,{ }^{8}$ had been drawn up in haste and was meant to be merely provisional. Its adoption had been accompanied by solemn promises by all parties represented in parliament of a new constitution to be made shortly after Iceland's declaration of full independence from Denmark in 1944. This promise was not, however, honoured until after the financial crash of 2008. As the coalition government of the Social Democratic Alliance and the Independence Party was ousted from office in early 2009, the Social Democrats went on to form a minority government with the Left-Green Party. The government needed the support of the Progressive Party which made its support conditional on having a new constitution put in place, to be drafted by the people rather than by politicians. Some thought that the prospects of a fundamental revision of the constitution - which essentially dates from the Danish era - were heightened by the fact that Social Democrat Jóhanna Sigurðardóttir became prime minister because, as an MP, she had advocated constitutional reform. After the 2009 election, the two parties of the minority coalition were able to form a majority

Crisis: The Politics of Blame, Protest, and Reconstruction (Routledge 2016); H Landemore, 'Inclusive Constitution-Making: The Icelandic Experiment' (2015) 23(2) Journal of Political Philosophy 166.

${ }^{6}$ The literature often distinguishes 'content effects' - understood as the impacts of participation on the final constitutional texts - and 'attitude effects' - which refer to a potentially higher degree of acceptance of a constitution that came into being with the help of the public. As this chapter focuses on the digital tools used, these categories do not appear as such. Z Elkins, T Ginsburg, and J Melton, 'A Review of Iceland's Draft Constitution', (2012) <http://comparativeconstitutionsproject.org/wp-content/uploads/CCP-Iceland-Report.pdf> accessed 26 January 2016; S Voight, 'The Consequences of Popular Participation in Constitutional Choice toward a Comparative Analysis', in A van Aaken, C List and C Luetge (eds), Deliberation and Decision (Ashgate 2009); C Klein and A Sajó, 'Constitution-Making: Process and Substance' in M Rosenfeld and A Sajó (eds.), Oxford Handbook of Comparative Constitutional Law (Oxford University Press 2012), 424.

${ }^{7}$ ACM Meuwese, 'Popular constitution-making. The case of Iceland', in D Galligan and M Versteeg (eds.), The social and political foundations of constitutions (Cambridge University Press 2013).

${ }^{8}$ On the 1,000th anniversary of the settlement of Iceland in 1874 Christian IX, King of Denmark, brought the Icelanders their first constitution, essentially identical to the Danish constitution of 1849. 
government, also headed by Ms. Sigurðardóttir. An attempt at constitutional overhaul seemed inevitable at this stage, with the Independence Party, a conservative force in Icelandic politics, reluctantly agreeing to a bill regulating the constitutional revision process. ${ }^{9}$ This support was considered important as it fostered the belief that having all parliamentary parties on board would benefit the project. However, this belief underestimated the long shadow of constitution-making history in the country. The two most significant amendments to the Icelandic Constitution - necessary to make the right to vote more equal by reducing the overrepresentation of rural areas in parliament - were approved by parliament in 1942 and 1959 in the face of fierce opposition of the Progressive Party, for many years the main beneficiary of unequal voting rights. The animosity created by these amendments is why the Independence Party and the Progressive Party, the two largest parties until 1999, were not on speaking terms for several years following each episode. During the parliamentary term 20092013, after a financial crash following those two parties' crony privatization of the banks in the years 1998-2003, the two parties found themselves together in opposition in parliament for the first time in history.

On June 16, 2010 the parliament (Althing) passed the Act on a Constitutional Assembly that should convene between February 15 and April 15, 2011. ${ }^{10}$ Thus, the original plan was to allocate to the work half the time that it took to draft the US Constitution in Philadelphia in 1787. The process also included the preparation of the drafting by a Constitutional Committee, consisting of seven professionals, lawyers as well as academics from other disciplines, appointed by parliament. The role of the committee was to organize a National Assembly (also known as National Forum) and prepare written background material for the Constitutional Assembly. A National Assembly comprising 950 individuals drawn at random from the National Register convened for a day in late 2010. It concluded that a new constitution was needed and that it should include certain key provisions on, e.g., equal voting rights and public ownership of natural resources. Soon after, a national Single Transferable Vote election of 25 Constitutional Assembly representatives from a roster of 522 candidates was held. ${ }^{11}$ Simultaneously, the Constitutional Committee produced a 700 -page report

\footnotetext{
9 ÁT Árnason, ‘A Review of the Icelandic Constitution - Popular Sovereignty or Political Confusion' [2011] Tijdschrift voor Constitutioneel Recht 342; ACM Meuwese, 'Popular constitution-making. The case of Iceland', in D Galligan and M Versteeg (eds.), The social and political foundations of constitutions (Cambridge University Press 2013).

10 ÁT Árnason, ‘A Review of the Icelandic Constitution - Popular Sovereignty or Political Confusion' [2011] Tijdschrift voor Constitutioneel Recht, 342, 343, 348

${ }^{11}$ The STV method is designed to minimize the number of dead votes. T Helgason, 'Greining á úrslitum kosningar til stjórnlagapings 27 nóvember 2010' (Analysis of the results of the Constitutional Assembly election November 27 2010)' (2011) 7(1) Icelandic Review of Politics and Administration, 40.
} 
analysing the 1944 Constitution and including suggestions of new constitutional text for the Constitutional Assembly to consider.

The wider context of dissatisfaction with the institutions and the political culture is important for a full understanding of the role that popular participation came to play. For one thing, on September 28, 2010 parliament resolved unanimously that "criticism of Iceland"s political culture must be taken seriously and [parliament] stresses the need for lessons to be learned from it. Parliament resolves that the report of the Special Investigation Commission of the parliament constitutes a condemnation of the government, politicians, and public administration" 12 . For an accurate, contextual understanding of this resolution several noteworthy features of Iceland's parliamentary democracy need to be taken into account.

First, the constitutional system acquired a semi-presidential flavour when the Icelandic governor, during a political impasse in the 1940s, secured support for having the president of the Republic elected directly by the people in an otherwise parliamentary system. ${ }^{13}$ Second, partly as a result of the significant and only gradually declining overrepresentation of rural areas in parliament, Iceland's parliamentary system has been permeated by patronage, ${ }^{14} \mathrm{a}$ phenomenon also well known in other countries including the United States. ${ }^{15}$ Footprints of this can be seen in the scattering of large infrastructural projects across the island. Third, corporatism is pervasive in Iceland. It is common for special interest groups - boat owners, bankers, farmers - to assist in the drafting of legislation and for employers and labour unions to dictate policy measures to the government. ${ }^{16}$ Fourth, Iceland's political culture is tainted by secrecy and instances of nepotism. Examples include the lack of transparency of the privatization of the banks $1998-2003,{ }^{17}$ recent cases of valuable bank assets being sold at modest prices to well-connected buyers and judicial appointments of friends and family of a

\footnotetext{
12 T Gylfason, 'Iceland: How Could This Happen?' in TM Andersen, M Bergman and SE Hougaard Jensen (eds.), Reform Capacity and Macroeconomic Performance in the Nordic Countries (Oxford University Press 2015), 7

${ }^{13}$ T Gylfason, 'From Collapse to Constitution: The Case of Iceland', in L Paganetto (ed.), Public Debt, Global Governance and Economic Dynamism (Springer 2013).

${ }^{14}$ S Kristjánsson, 'Iceland: A Parliamentary Democracy with a Semi-Presidential Constitution' in K Ström, WC Müller, and T Bergman (eds.), Delegation and Accountability in Parliamentary Democracies (Oxford University Press 2003), 413; ÁT Árnason, 'A Review of the Icelandic Constitution - Popular Sovereignty or Political Confusion’ [2011] Tijdschrift voor Constitutioneel Recht 342, 345.

${ }^{15}$ S Levinson, Our Undemocratic Constitution: Where the Constitution Goes Wrong (and How We the People Can Correct It) (Oxford University Press 2006), see chapter 2.

${ }^{16}$ S Kristjánsson, 'Iceland: A Parliamentary Democracy with a Semi-Presidential Constitution' in K Ström, WC Müller and T Bergman (eds.), Delegation and Accountability in Parliamentary Democracies (Oxford University Press 2003), 413.

${ }^{17}$ It was not until the post-crash government came to office in 2009 that several key documents on the bank privatization process were disclosed by the prime minister's office to the public. Even so, the parliament waited until late 2012 to resolve to launch an investigation of the privatization, but failed to implement its resolution.
} 
former prime minister. ${ }^{18}$

The country's anger at its political class after the crash also found an outlet through judicial means when the former prime minister Geir Haarde from the Independence Party was indicted by parliament in September $2010 .{ }^{19} \mathrm{He}$ was subsequently cleared of all but one charge, namely that - in violation of the constitution - he failed to keep his ministers sufficiently informed during the 2008 financial crisis. ${ }^{20}$ An ad hoc parliamentary committee had determined that four former ministers should be indicted, but parliament, including current and former ministers who did not recuse themselves from the proceedings, decided to exonerate all except the former prime minister. This led the Independence Party to practically declare war on the government, thus extinguishing the hope that government and opposition could unite in honouring their promise to the people of a new constitution.

The position of the president in the 1944 Constitution had long been taken for granted. The Constitution states that the president has a constitutional right to refer legislation to a national referendum. This provision was used for the first time in 2004 when the president refused to sign a bill on media ownership, citing not his conscience but rather a chasm between parliament and public opinion. ${ }^{21}$ The 1944 Constitution stipulates that the statute in question still enters into force but must be put to a referendum within two months. Without explicit constitutional authority to do so, the government chose to withdraw the bill. Iceland's semi-presidential parliamentary system was thus seen to function as intended, to the great displeasure of MPs across the spectrum. Several of them had argued, with the support of some law professors, that the fact that the constitutional authority of the president to veto legislation had lain dormant for 60 years, had somehow invalidated this provision. ${ }^{22}$ This state of affairs made it clear to many Icelanders that a new constitution was needed to clarify the situation, either by reaffirming or perhaps modifying the semi-presidential setup of the 1944 Constitution or by making an explicit move either to a presidential system or to a

\footnotetext{
${ }^{18}$ In one case an applicant more qualified for the job than the prime minister's son was awarded damages. T Gylfason, 'Crowds and Constitutions', (13 October 2011) <http://voxeu.org/article/crowds-and-constitutionsinsights-iceland> accessed 11 March 2016.

${ }^{19}$ See Special Investigation Commission (SIC), 'Report of the Special Investigation Commission (SIC)' (12 April 2010) delivered to the Icelandic Parliament <www.rna.is/eldri-nefndir/addragandi-og-orsakir-fallsislensku-bankanna-2008/skyrsla-nefndarinnar/english/> accessed 24 January 2016.

${ }^{20} \mathrm{~J}$ Werdigier, 'Dealbook; Ex-premier of Iceland convicted in '08 crisis', (2012) <http://query.nytimes.com/gst/fullpage.html?res=9A07E3DD1339F937A15757C0A9649D8B63> accessed 11 March 2016.

${ }^{21} \mathrm{~J}$ Ólafsson, 'An Experiment in Iceland: Crowdsourcing a Constitution?' (2012) Working Paper, <www.yale.edu/polisci/conferences/epistemic_democracy/jOlafsson.pdf> accessed 11 March 2016.

${ }^{22}$ T Gylfason, 'From Collapse to Constitution: The Case of Iceland', in L Paganetto (ed.), Public Debt, Global Governance and Economic Dynamism (Springer 2013).
} 
parliamentary one with only a ceremonial role for the president. In fact, members of one of several (ineffective) constitutional committees appointed by parliament over the years, launched in 2005, aimed to remove the president's authority to veto legislation from the Constitution but failed. In the Constitutional Council, there was little support for giving more power or less power to the president; indeed, the National Assembly provided no instructions either way in this regard. The support for a stronger presidency was weakened by the incumbent president's perceived closeness to the bankers held, along with politicians, responsible for the 2008 crash. $^{23}$ On the other hand, the support for a less consequential presidency was weakened by the need to create a better balance between the three branches of government to limit executive overreach. ${ }^{24}$ Even so, the Council bill aims to clarify the role of the president.

Against the backdrop of the financial crisis, the perception of governmental misconduct strengthened the case for constitutional reform. As one observer put it: 'It is demonstrative of the pathos [...] afflicting the Icelandic political elites that not only the people but also the politicians no longer trusted themselves to adequately re-write a Constitution that would attain popular legitimacy ${ }^{25}$. Angry demonstrators were banging their pots and pans, not only outside parliament but also in the social media, which Icelanders were quick to embrace and to use tirelessly to express their dismay at Iceland's politicians. The timing was perfect: the emergence of Facebook preceded Iceland's financial collapse only by a couple of years.

Some observers, including Iceland's president, have claimed that the idea that constitutional change can only happen through consensus is deeply rooted in Icelandic culture. This view is not supported by history in the sense that any requirement of consensus has obstructed meaningful change in the past. A series of parliamentary constitutional committees comprising representatives of all parties in parliament failed to significantly revise the Constitution. When significant change was accomplished, consensus had to be abandoned. This is illustrated by the two most significant amendments to the 1944 Constitution - accomplished in 1942 and 1959 - which resulted in deep and long-lasting political divisions. ${ }^{26}$ The absence of consensus is in fact inevitable because constitutions are

\footnotetext{
${ }^{23}$ J Ólafsson, 'An Experiment in Iceland: Crowdsourcing a Constitution?' (2012) Working Paper, $<$ www.yale.edu/polisci/conferences/epistemic_democracy/jOlafsson.pdf> accessed 11 March 2016.

${ }^{24}$ T Gylfason, 'From Collapse to Constitution: The Case of Iceland', in L Paganetto (ed.), Public Debt, Global Governance and Economic Dynamism (Springer 2013).

${ }^{25} \mathrm{R}$ Bater, 'Hope from Below: Composing the Commons in Iceland' (1 December 2011) <

www.opendemocracy.net/richard-bater/hope-from-below-composing-commons-in-iceland $>$ accessed 24 January 2016.

${ }^{26}$ Two further significant amendments can be said to have been made: the first was made in 1984, when voting rights were equalized slightly once again. This amendment was enough to eliminate the last vestiges of the long-
} 
meant to demarcate rights and obligations. Those asked to give up their privileges (e.g., Iceland's vessel owners) and to shoulder obligations (e.g., to stop polluting the environment) will oppose a constitution aiming to accomplish this. ${ }^{27}$ But even some of those advocating the idea that constitutional change requires consensus realized that the shock of the crisis might override this way of thinking. ${ }^{28}$ Three months after the adoption of the Act on a Constitutional Assembly in June 2010, severe disagreement erupted in parliament following the aforementioned indictment of the former prime minister.

The virtual state of war within parliament was probably instrumental in producing the three technical complaints levied by individuals connected to the Independence Party against the Constitutional Council election held November 27, 2010. Six Supreme Court judges, five of them Independence Party appointees, issued an administrative decision on January 25, 2011 declaring the election null and void on flimsy technical grounds even if no one, not even those filing the complaints, had suggested that the alleged technical flaws had affected the election results.

Rather than repeat the election, which would have created all sorts of problems, parliament decided to appoint the 25 elected representatives to a Constitutional Council which earlier legislation had referred to as a Constitutional Assembly. Undeterred by these events, in a role that was formally of an advisory nature, but with a strong mandate and high expectations on the part of the public, the Constitutional Council started its work on April 6, 2011. It had the 700-page background report by the Constitutional Committee, the conclusions of the National Assembly, and preparatory work by individual representatives to draw on. The Council convened for close to four months, from April 6 until July 28, 2011, unanimously - i.e., with 25 votes against zero - approving the constitutional bill on July 27 , presenting a polished version to the speaker of parliament two days later. No other MPs attended the ceremony, a harbinger of things to come.

How was it possible to produce and unanimously pass a constitutional bill combining continuity with fairly radical reform in several areas - including equal voting rights, national

\footnotetext{
standing bias in favour of the Progressive Party, though not the bias in favour of rural areas, which remains strong. The second significant amendment was made in 1995 when a few human rights provisions were added to the 1944 constitution.

${ }^{27}$ This is why the Federalists were so firmly opposed by the Anti-Federalists in the United States in 1787-1788, why the US constitution was supported by only 39 of the 55 delegates in Philadelphia and why it was approved by such low margins in several of the state referenda thereafter. P Maier, Ratification: The People Debate the Constitution, 1787-1788 (Simon and Schuster 2010); T Gylfason, 'Constitutions: Financial Crisis Can Lead to Change' (2012) 55(5) Challenge, 106.

${ }^{28}$ House of Commons, 2011. Corrected transcript of oral evidence taken before the Political and Constitutional Reform Committee, 'Mapping the Path to Codifying - or not Codifying - the UK's Constitution', Questions to Professor Guðmundur Hálfdánarson, (July 14 2011), HC 1178-ii.
} 
ownership of natural resources, freedom of information, ambitious environmental protection, and more? We propose three main reasons. First, with only one exception, ${ }^{29}$ concerning the number of MPs, the bill was consistent with the conclusions of the National Assembly in November $2010 .{ }^{30}$ Second, public opinion polls reflected a broad consensus on key constitutional issues; in particular, there was no significant difference between the views expressed by the general public, the 522 Constitutional Council candidates, and the 25 elected representatives. Third, the method used to elect the Council members - one person, one vote combined with STV - produced a group of uniformly competent people from different walks of life with a wide range of professional experience, including eight academics used to soliciting outside expertise. In the first few days of the Council's deliberations, it was decided to draft a new constitution from scratch, as was done in Philadelphia in 1787, rather than amend the 1944 Constitution. This was done with due respect for constitutional continuity as Elkins et al. emphasize in their review of the bill. ${ }^{31}$ Also, it was decided to invite outsiders to participate through a specially designed interactive website as well as through social media.

A successful computer gaming company in Iceland introduced the Council and its staff to interactive methods which the Council decided to apply by approaching the drafting process in weekly episodes. The Council website was designed around this process. Every Friday a new version of the bill was published online enabling interested parties to compare it with older versions and to comment on the updates. In total, there were 11 revisions made to the document with more than 3,600 discussion threads posted. This was a way to underscore the popular nature of the constitution-making exercise as opposed to constitution-making by politicians and their lawyers. The open invitation to the public had an important additional benefit: it made it unnecessary - indeed, inappropriate - to invite representatives of interest groups to meet with the Council or with individual Council members as happened, for example, when the South African Constitution was put together during 1994-1996. This invitation was in line with the opening salvo of the preamble: "We, the people of Iceland, wish to create a just society with equal opportunities for everyone."

\footnotetext{
29 The National Assembly called for a reduction in the number of seats in parliament. The bill stipulates an unchanged number of seats so as not to compromise the impression that the bill aims to strengthen the position of parliament and the courts against the executive branch.

${ }^{30}$ T Gylfason, 'Constitution on Ice', (2014a) CESifo Working Paper No. 5056. Forthcoming in Ingimundarson et al. (eds.) Iceland's Financial Crisis: The Politics of Blame, Protest, and Reconstruction (Routledge 2016).

${ }^{31}$ Z Elkins, T Ginsburg and J Melton, 'A Review of Iceland's Draft Constitution', (2012)

$<$ http://comparativeconstitutionsproject.org/wp-content/uploads/CCP-Iceland-Report.pdf> accessed 26 January 2016.
} 
After some back-and-forth between the parliament and the Constitutional Council, parliament called for an extra four-day Council meeting in spring 2012 for the Council to answer some specific questions about the text of the original bill. At this meeting the 21 Council members present - four of the 25 could not attend - gave unanimous answers to the parliament's queries, in some cases suggesting alternative formulations without changing the substance of the provisions in question. Not long thereafter, parliament decided to put the bill to a referendum. By now, the opposition in parliament - the Independence Party and also the Progressives who had reversed course - were fighting tooth and nail against the reform process, managing to delay the referendum beyond the presidential election of June 30, 2012, a date preferred by the government on the grounds that voter turnout is always high in presidential elections. Instead, the referendum was held on October 20, 2012. The bill as a whole as well as its key provisions put on the ballot by parliament won overwhelming support across the board with only two exceptions: the provision on equal voting rights was not accepted in two of the three rural constituencies and the provision on church and state was not approved. The overall support for the bill was 67 per cent, the support for equal voting rights was also 67 per cent, and for national ownership of natural resources 83 per cent. The turnout was 49 per cent, a remarkably high figure in view of the fact that the referendum was a political orphan. Even the government coalition parties that called the referendum did almost nothing to promote the bill or to encourage their supporters to vote. It fell on the smallest party in parliament, an opposition party with 3 seats out of 63 , as well as on ordinary citizens, including some former Constitutional Council members, to travel around the country to discuss the bill with the voters.

The opponents of the bill resorted to peculiar arguments. They claimed not to have had enough time to study the bill while simultaneously staging the most extensive filibuster in the parliament's history. They claimed that those who did not show up to vote did so because they were against the bill. They also stated that a 49 per cent turnout was not enough even if Icelandic law has no provision on minimum voter turnout. Finally, they argued that the first question on the ballot - that they had helped phrase - 'Do you want the proposals of the Constitutional Council to form the basis of a legislative bill for a new Constitution?,' allowed them to build anything of their liking on this 'basis'. To the proponents of the bill a reasonable interpretation of the referendum result is that the 'yes' vote allowed parliament to make, if any, only editorial or technical changes. This was, indeed, the understanding of the parliament's Constitutional and Supervisory Committee in charge of the bill 2011-2013. Yet, in spite of the overwhelming 'yes' vote, opponents insisted on interpreting the term 'basis' in 
the question posed as 'mere basis'. After the referendum, the haggling in parliament intensified. Two MPs left an extensive written record of events, one in a book ${ }^{32}$ and the other in an interview. ${ }^{33}$ The passive majority in parliament that had shown little interest in the referendum proved an easy prey for the fierce opponents in the minority which, with the economy gradually recovering under the IMF-supported rescue programme, sensed that the shadow of the financial crash was growing shorter. Even if 32 MPs out of 63 had in writing declared their support for the ratification of the bill by parliament in accordance with the outcome of the referendum, parliament adjourned in March 2013 without having put the bill to a vote because the majority did not want to set a precedent by breaking the minority filibuster as permitted by law. Following this self-inflicted defeat, the outgoing prime minister Jóhanna Sigurðardóttir was reported by Icelandic State Radio as saying: 'The past few weeks were the saddest period of my 35 years in Parliament.' A month later her party suffered the greatest defeat in the history of parliamentary elections in Iceland, losing 57 per cent of their vote compared with the 2009 election.

According to Iceland's 1944 Constitution, constitutional amendments require a simple majority in two successive parliaments with a general election in between. The strategy of the supporters of the bill was to pass the bill unanimously in the Constitutional Council and go on to win the referendum by a solid majority of the voters, thus making it inevitable for parliament to ratify the bill before the 2013 election. This would, ultimately, make it difficult for a new parliament, after the 2013 election, to refuse to provide the second ratification without provoking riots. This strategy failed because Ásta Ragnheiður Jóhannesdóttir, speaker of parliament, in violation of parliamentary procedure, failed to bring the bill to a vote before parliament adjourned on March 27, 2013.

\section{Digital constitution-making?}

Since the constitutional draft prepared by the Constitutional Council and approved in a national referendum has not yet made it to the stage of actual adoption, the label 'the world's first crowdsourced constitution', often touted in the international media, ${ }^{34}$ needs to be replaced for the time being by 'the world's first crowdsourced constitution bill.' Apart from

\footnotetext{
${ }^{32}$ M Tryggvadóttir, Útistöður (Quarrels) (Reykjavík, Hansen og synir, 2014).

${ }^{33}$ T Gylfason, 'Tvöfalt líf: Porvaldur Gylfason ræðir við Práin Bertelsson (Double Life: Thorvaldur Gylfason Interviews Thráinn Bertelsson)' (2014) 4 Tímarit Máls og menningar (Journal of Language and Culture) 1. ${ }^{34}$ E.g. 'Icelanders back first 'crowdsourced constitution', EurActiv.com, (October 22 2012)

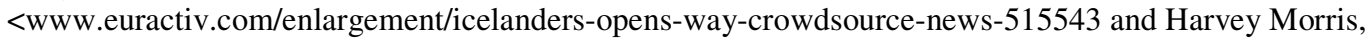
'CCrowdsourcing Iceland's Constitution', New York Times (view from Europe)' (October 24 2012) $<$ http://rendezvous.blogs.nytimes.com/2012/10/24/crowdsourcing-icelands-constitution/?_r=0> accessed 11 March 2016.
} 
the substance of the bill, several digital features of the drafting process are worth close study as there are important lessons to be learnt, especially when the use of digital tools is linked to the wider context of the Icelandic experiment. This section starts out by listing the uses of digital tools and proceeds to describe how these were interlinked with the drafting process and, where applicable, the substance of the proposed provisions.

\section{A. Digital tools in the drafting process}

Inclusiveness and digital democracy have an ambivalent relationship, even in Iceland, despite its record-high per capita number of internet users. There are always some 'unconnected citizens' who are excluded altogether if the process relies too heavily on internet-based digital tools. This is even more important because vulnerable citizens are likely to be overrepresented in this group. Constitution Council members decided to allow their phone numbers to be published, or rather not to have them removed from the telephone catalogue which would have been impractical anyway in view of the time frame, and to answer letters and phone calls as well. ${ }^{35}$ The Constitutional Council was free to make such decisions as it was authorised by law to establish its own procedures and governance. It was the Council's intention from the start that the drafting process would be as open as possible to members of the public.

The first category of tools comprised the extensive social media applications actively used by the Council. When considering these, we need to keep in mind that the drafting took place during mid-2011 when social media use was a bit different from what it is today. Active presence in social media was not quite yet the 'obligatory feature' for actors in the public sphere that it became just a few years later. Social media were already widely used by political institutions in our part of the world, ${ }^{36}$ but often mainly as window-dressing or for information dispersion purposes at best. At the time, the use of these fora to actively solicit input from the public was an innovative feature. The Council employed two computer experts to facilitate all technical aspects of the work, including social media use.

An important social media tool was the Council's Facebook page where Council members and staff made a point of trying to respond to most queries, comments, and suggestions. Several suggestions from the public appeared to focus on a radically different economic model for the country whereas others concerned issues such as web neutrality, transparency,

\footnotetext{
${ }^{35}$ T Gylfason, 'From Collapse to Constitution: The Case of Iceland', in L Paganetto (ed.), Public Debt, Global Governance and Economic Dynamism (Springer 2013)

${ }^{36}$ C Shirky, 'The Political Power of Social Media' (2011) 90(1) Foreign Affairs.
} 
and access to the internet. ${ }^{37}$ Apart from a few 'statement' suggestions, such as a proposal to ban all private banks, the vast majority of the comments received from outside observers were serious, thoughtful, and quite useful, and several found their way into the final version of the bill. ${ }^{38}$ Furthermore, most Council members were active on Facebook; some of them launched their Facebook pages in preparation for their candidacy in the Constitutional Assembly election of 2010 when Facebook was still quite new to Iceland.

Twitter was also used, mostly in English, after foreign media expressed interest in this aspect of the Council's working methods. ${ }^{39}$ One concrete example is the contribution by the Constitutional Analysis Support Team (CAST) which described itself as a 'semi-formal collective of individuals sharing an interest in the Constitution process.' CAST was established in January 2011 with the aim of analysing elements of the new constitution under consideration during the drafting process. The Council cooperated with CAST when it organized a Constitution 'Stress Test' - 'an event open to citizens with a willingness to contribute to testing and finding gaps in the Constitution.' The results were tweeted while the 'stress test' was ongoing. According to Bater, the summary report of the findings on CAST's website was consulted by Council members. ${ }^{40}$ Flickr was used for all photos and issuu.com was used for the electronic dissemination of the work.

Google software proved useful as well. Google Docs was used to draft text in committees and Google Translate was used by foreign observers to follow what was going on, enabling them also to contribute comments and suggestions. When the parliament declined to finance an English translation of the bill after it was completed, foreign observers had to rely on Google Translate until a retired Central Bank economist submitted a layman's translation of the bill. A little later, the Constitutional Society, a non-profit NGO, financed a translation of the bill into English by a certified translator. When parliament in November 2012 decided at the eleventh hour to seek the views of the Venice Commission, it was this version that it sent to Venice, with the permission of the Constitutional Society.

The Council's own website constitutes a second category of its own. ${ }^{41}$ The Council's technical experts designed from scratch an interactive constitution-making website with

\footnotetext{
${ }^{37}$ A Valdimarsdóttir, 'Icelanders hand in draft of world's first 'web' constitution', July 29 2011, quoting Council member Silja Bára Ómarsdóttir.

${ }^{38}$ Personal observation by one of the authors who was a member of the Constitutional Council.

${ }^{39}$ See <http://twitter.com/stjornlagarad $>$.

${ }^{40} \mathrm{R}$ Bater, 'Hope from Below: Composing the Commons in Iceland' (1 December 2011)

$<$ www.opendemocracy.net/richard-bater/hope-from-below-composing-commons-in-iceland $>$ accessed 24 January 2016.

${ }^{41}$ This phenomenon should not be confused with 'wiki-constitutionalism', a term that refers to the constant rewriting of constitutions in certain countries in South America. See Claes (2011, p.100), who refers to Daniel
} 
features that resemble some media websites, enabling external users to insert comments and engage other users, including Council members, in conversation. Some reluctance about this feature was expressed at first but it faded away quickly when it became clear how civilised and constructive the external contributions to the conversation proved to be. Thus, the conversation between Council members and outside participants took place on the website as well as on Facebook, not only on the Council Facebook page, but also on individual Council members' pages. In retrospect, it is curious that reservations were expressed about the interactive features of the website, but not about opening a Facebook page which shares the same feature. The Icelandic expert who designed the website has been called upon to give technical advice to constitution makers in other countries. ${ }^{42}$

A third category comprises the extensive use of video-streaming of the deliberations by the Council. Committee meetings, however, were generally held behind closed doors to encourage frank discussions at the initial drafting stage, except when Council members from the other two committees - there were three such committees - were invited to participate or when external experts were asked to give advice. The broadcasts offered were more popular than might be expected, with a regular audience of 150-450 viewers for the broadcasts of the open Council meetings which took place every Thursday. ${ }^{43}$ In view of the small size of Iceland's population ( 0.3 million) and the fact that streaming broadcasts of political debates are not generally known for their popularity, this is quite remarkable. YouTube was used extensively, both to upload speeches by Council members in the open sessions as well as interviews with them, some of them taken in-house by the Council's press secretary to inform the public of the goings on.

The end result in quantitative terms was a total number of 3,600 comments received in addition to some 320 formal suggestions from citizens, which were all discussed and answered by the three committees of the Council. ${ }^{44}$

\section{B. Interaction with the drafting process}

The Constitutional Council actively and explicitly turned the 'golden triangle' of transparency, equal access, and technology into a leitmotiv of its working method. It was

Lansberg-Rodriguez, 'Wiki-constitutionalism. The strange phenomenon that's destroying Latin America', The New Republican, May 25 2010. Claes observes that the term wiki-constitutionalism is confusing here since it implies broad participation through an open-source infrastructure, which is in fact not a feature of the processes 'wiki-constitutionalism' is referring to.

${ }^{42}$ Personal observation by one of the authors who was a member of the Constitutional Council.

${ }^{43}$ T Gylfason, 'Crowds and Constitutions' (13 October 2011) <Voxeu.org> accessed 11 March 2016.

${ }^{44}$ T Gylfason, 'From Collapse to Constitution: The Case of Iceland', in L Paganetto (ed.), Public Debt, Global Governance and Economic Dynamism (Springer 2013). 
considered important not to follow 'standard operating procedure in parliamentary work' and 'not invite representatives of interest organisations to special meetings' ${ }^{45}$ This decision reflected the conviction that any semblance of playing political games was incompatible with the Council's mandate. ${ }^{46}$ In particular, the Council was adamant that MPs would not be granted special status in the drafting process. Instead, the Council held general meetings to which the public, within reasonable non-binding limits of space, was invited. No MP tried to interfere with the work of the Council as far as is known, nor did representatives of interest groups seek to make their views known, perhaps because they were not used to being invited to a seat at the same table as everyone else.

Digital applications played a role that was broader than soliciting input. They were also used to stay in contact with the public when it did not necessarily have a contribution to make, but was concerned about the state of play during the inevitably more closed phases of the Council's tenure. Staffers reassured people that up until the final decision on the draft, the Council would be reachable. In other words: in Iceland, participation in constitution-making was not only about 'what was said, but also [about] the things left unsaid' ${ }^{\text {' }}$. Concretely, provided that the information presented was full and up to date, the fact that no objections were being uttered proved valuable input for the drafters, too.

Two related benefits of popular participation also merit mentioning. One benefit was the feeling of ownership encouraged by the open invitation to the public which helped create the sentiment that this was indeed a constitutional bill for the people and drafted by the people. This collective sentiment may go a long way towards explaining the strong support for the bill in the 2012 referendum. The other benefit was the clear message that special interest groups were not being offered special treatment, a message that strengthened the feeling of popular ownership.

The Council tried to continuously update the information on its website and social media sites. Proposals for constitutional provisions were posted in batches on the Council website, even quite provisional drafts, usually with intervals of two or three weeks, to make the input from the public as relevant as possible.

Admittedly, the manner of taking external input into account was rather haphazard, which is hardly surprising given the lack of a clear methodology for processing digital consultation

\footnotetext{
${ }^{45}$ T Gylfason, 'Crowds and Constitutions', (13 October 2011) <Voxeu.org> accessed 11 March 2016.

${ }^{46}$ J Ólafsson, 'An Experiment in Iceland: Crowdsourcing a Constitution?' (2012) Working Paper, $<$ www.yale.edu/polisci/conferences/epistemic_democracy/jOlafsson.pdf> accessed 11 March 2016.

${ }^{47}$ T Gylfason, 'Crowds and Constitutions', (13 October 2011) <Voxeu.org> accessed 11 March 2016.
} 
input. ${ }^{48}$ Social media routines and e-consultation software applications were not yet what they are today. The Council engaged in trial and error. Its members generally thought it more important to debate substantive points amongst themselves and with external observers than to keep records of everything that went on. Secretaries kept minutes at all meetings of the Council, its three committees, and its governing board, that were gradually made public on the Council website, where they remain, but only in Icelandic.

When the time came to decide on the final text of the bill, votes were cast first on each individual article and at last on the bill as a whole. Each provision was approved by an overwhelming majority and the bill as a whole was adopted unanimously. ${ }^{49}$ The votes on equal voting rights and national ownership of natural resources were followed by spontaneous applause. In line with the guiding principles of transparency, equal access, and technology the Council representatives insisted on remaining open to reconsideration of issues in the run-up to the referendum if needed..$^{50}$

\section{Interaction with the world}

At the core of the Icelandic process was a strong conviction which may be characterized as being loosely based on rational choice theory: parliaments are actually not well placed to write or revise constitutions because MPs have vested interests in the organizational structure of the state. ${ }^{51}$ This normative issue at the heart of the Icelandic experiment is connected to a positive development. Even if the question 'who should write constitutions?' has always been hard to answer, the availability of various electronic and social media tools makes it even harder because, in practical terms, the options are no longer limited to domestic residents.

One aspect of the Icelandic experiment that should not be overlooked is that, because of the use of digital technology in the drafting process, anyone, and not just Icelandic citizens, could join the deliberations. The Constitutional Council even actively encouraged a degree of 'global participation' through its active use of English in all sorts of communications, including a generous treatment of translation requests.

Did the fact that some comments on the Council's website came from people from all over the world undermine the people's ownership of the new Constitution? Many thought that

\footnotetext{
48 J Ólafsson, ‘An Experiment in Iceland: Crowdsourcing a Constitution?' (2012) Working Paper, $<$ www.yale.edu/polisci/conferences/epistemic_democracy/jOlafsson.pdf> accessed 11 March 2016.

${ }^{49}$ T Gylfason, 'Crowds and Constitutions', (13 October 2011) <Voxeu.org> accessed 11 March 2016.

${ }^{50} \mathrm{See}<\mathrm{http}: / /$ stjornlagarad.is/english/ $\geq$.

${ }^{51}$ T Gylfason, 'From Collapse to Constitution: The Case of Iceland', in L Paganetto (ed.), Public Debt, Global Governance and Economic Dynamism (Springer 2013), 11; J Elster, 'Icelandic Constitution-making in Comparative Perspective', in Ingimundarson et al. (eds.), Iceland's Financial Crisis: The Politics of Blame, Protest, and Reconstruction (Routledge 2016).
} 
foreign involvement enriched the process, especially because the rewriting of the constitution - and of any constitution, for that matter - was always going to involve the use of other people's ideas. Awareneess of the Council's status as global pioneer may also have played a role. Furthermore, the foreign contributions received were few compared with local ones. Iceland has a long tradition of borrowing and adapting policy solutions from other countries, particularly the Nordic countries. Constitutional solutions studied by Council members came from a number of places, including Finland, Sweden, and Germany. ${ }^{52}$ Councillors were inspired by academic studies as well as by foreign constitutions. ${ }^{53}$

\section{Interaction with the content of the proposal}

The new Icelandic constitutional bill consists of nine chapters, containing a total of 114 articles, preceded by a preamble. Whether some parts of the bill were influenced more strongly than others by public participation in the process is hard to determine on the basis of the available data. The Facebook conversation is mostly still available. The comments and suggestions recorded on the Council website are still there, but an analysis of the correlation between the external input and the text of the bill is complicated by the fact that there are no records of the way in which the input was processed and responded to. We limited ourselves to a few suggestions regarding the preamble as well as the provisions regarding the presidency, the electoral system, open government, and natural resource management. ${ }^{54}$

Would a preamble, a feature absent from other Nordic constitutions, have been included without public participation? Perhaps. In any case, it seems reasonable to suppose that the regular contact of Council members with citizens throughout the drafting process may have contributed to the uplifting spirit of the preamble: 'We, the people of Iceland, wish to create a just society with equal opportunities for everyone. Our different origins enrich the whole, and together we are responsible for the heritage of the generations, the land and history, nature, language and culture.' One of Iceland's foremost living poets, Mr. Hannes Pétursson, was consulted informally on the wording of the preamble. ${ }^{55}$ Notice the first person plural which

\footnotetext{
${ }^{52}$ Personal communication by a Council member; even Bhutan and Bolivia were on their radar screen.

${ }^{53}$ As illustrated by the following quote: "With each passing meeting, the $\mathrm{CC}$ attempted to achieve greater proximity between the written document and the sentiments of the people, whilst constantly referring also to 'state-of-the-art' constitutional practices from around the world", R Bater, 'Hope from Below: Composing the Commons in Iceland' (1 December 2011) < www.opendemocracy.net/richard-bater/hope-from-belowcomposing-commons-in-iceland> accessed 24 January 2016.

${ }^{54}$ ACM Meuwese, 'Popular constitution-making. The case of Iceland', in D Galligan and M Versteeg (eds.), The social and political foundations of constitutions (Cambridge University Press 2013).

${ }^{55}$ Council members Erlingur Sigurðarson, who is also a published poet, and Pastor Örn Bárður Jónsson, who has made hundreds of his funeral sermons available to the public on the Internet, contributed significantly to the preamble along with several others.
} 
recurs in several provisions of the bill, a clear departure from the 1944 Constitution. Icelandic has a rich and complex grammar, including three ways of expressing the words "We all" depending on gender: "Við allir" is male and "Við allar" is female whereas "Við öll" is neutral. The 1944 text always says “Allir”. The new text says "Öll” and sometimes “Við öll” to underline gender equality and inclusiveness. Local lawyers, hired by the parliament after the 2012 referendum to adjust wording under strict instructions not to change anything of substance, restored the formulation "Allir" everywhere in the text. Gylfason and Landemore give further examples of substantive changes for the worse proposed by the lawyers beyond their mandate. ${ }^{56}$

The contention surrounding the role and powers of the president has been central in constitutional debate in Iceland. Some have proposed strengthening the role of the president along French lines, for example. They felt that checks and balances were needed to rein in parliament and the cabinet. Others have proposed weakening the role of the president or abolishing the presidency altogether. ${ }^{57}$ Their motivation was that the president in office 19962016, Mr. Ólafur Ragnar Grímsson, had encroached on the parliament when he exercised his constitutional authority to veto legislation and refer it to a national referendum in 2004 and again in 2010 and 2011. The president's activation of his constitutional authority to veto legislation weakened the resolve of those wanting to reduce the role of the president. The parliament had been reined in and the people had spoken thanks to the president's vetoes. The elimination of this outlet would have been perceived as undemocratic. At the same time, the president's posture, including his brazen support of the bankers before the crash of 2008, as noted in the parliament's Special Investigation Commission report, ${ }^{58}$ had also unsettled those who had earlier favoured increased presidential authority as a counterbalance against parliament and the cabinet. This is probably why the Constitutional Council left the role of the president essentially unchanged. Whether the constitutional bill increases or reduces the power of the presidency is open for debate. Article 1 states - as does the 1944 Constitution that Iceland is a parliamentary democracy without explicitly describing it as 'semi-

\footnotetext{
${ }^{56}$ T Gylfason, 'Constitution on Ice' (2014) CESifo Working Paper No. 5056, forthcoming in Ingimundarson et al. (eds.), Iceland's Financial Crisis: The Politics of Blame, Protest, and Reconstruction (Routledge 2016); H Landemore, 'Inclusive Constitution-Making: The Icelandic Experiment' (2015) 23(2) Journal of Political Philosophy 166.

${ }^{57}$ An MP for the Independence Party proposed a constitutional amendment to abolish the presidency shortly after the president vetoed the parliament's media act in 2004. This amendment was not accepted. Since 1944, parliament has rejected or not acted on 100 proposed constitutional amendments of various kinds. See $<$ https://www.forsaetisraduneyti.is/stjornarskra/throun/breytingafrumvorp/>.

${ }^{58}$ Special Investigation Commission (SIC), "Report of the Special Investigation Commission (SIC)," delivered to the Icelandic Parliament (12 April 2010) <www.rna.is/eldri-nefndir/addragandi-og-orsakir-falls-islenskubankanna-2008/skyrsla-nefndarinnar/english/> accessed 24 January 2016, 8, 170-178.
} 
presidential' ${ }^{59}$ The power of the president can be said to be curtailed by granting 10 per cent of the voters the right to refer legislation to a referendum, thus making the president share his veto power with the voters, and by making some details of the procedure after a presidential veto more explicit. ${ }^{60}$ Whereas after the 2004 presidential veto of the media law it was a matter of dispute whether it was constitutional to withdraw the bill instead of putting it to a referendum, the parliament, according to the new bill, is explicitly granted authority to do so (Article 60). This slight curtailment of presidential powers can be said to be counterbalanced by giving the president a significant role in the appointment of certain public officials. This role, in conjunction with stronger justification demands, the establishment of a civil service commission, and a role for parliament in case of a presidential veto (Article 96), is seen by some as an attempt to curb the powers of ministers in this regard, and thus limit "appointment corruption". ${ }^{61}$ A quick scan of the Facebook activity between July 5 and 17, 2011 reveals some specific suggestions regarding the position of the president, for instance regarding the way the president is elected.

The proposed provisions on the electoral system, among the more radical ones, are arguably those where the effects of wide public participation are most visible. When Iceland's parliament (est. 930) reconvened in 1845, the number of MPs was 26, one for every 2,200 Icelanders. When the constitution from 1874 was amended in 1920, the number of MPs was increased to 42 in tandem with the increase in population. In 1943, the number of MPs was increased to 49 , lifting the population/MP ratio slightly to 2,300 . Then came the bitterly fought constitutional amendment of 1942, increasing the number of MPs to 52 (one for every 2,400 Icelanders) and again in 1959, when the number of MPs was raised to 60 (population/MP ratio of 2,800). The last such change was made in 1987 when the number of MPs was increased to its current level, 63 (population/MP ratio of 3,900). ${ }^{62}$ Since that time, population growth has increased the population/MP ratio to 5,200, a low ratio compared with other countries. ${ }^{63}$ The constitutional amendments of 1942, 1959, and 1987 were primarily intended to moderate the inequality of voting rights.

\footnotetext{
${ }^{59}$ Z Elkins, T Ginsburg, and J Melton, ‘A Review of Iceland's Draft Constitution', (2012) $<$ http://comparativeconstitutionsproject.org/wp-content/uploads/CCP-Iceland-Report.pdf > accessed 26 January 2016.

${ }^{60}$ Z Elkins, T Ginsburg, and J Melton, ‘A Review of Iceland's Draft Constitution', (2012)

$<$ http://comparativeconstitutionsproject.org/wp-content/uploads/CCP-Iceland-Report.pdf> accessed 26 January 2016.

${ }^{61}$ T Gylfason, 'From Collapse to Constitution: The Case of Iceland', in L Paganetto (ed.), Public Debt, Global Governance and Economic Dynamism (Springer 2013), 27.

${ }^{62}$ Unlike in 1942 and 1959, the change in 1987 was supported by the Progressive Party.

${ }^{63}$ The population/MP ratio is 27,000 in both Finland and Sweden, 31,000 in Denmark, 29,000 in Norway, and 10,000 in Barbados (whose population is the about same as in Iceland).
} 
Iceland is at present divided into six electoral districts: three in the Reykjavík area, where two thirds of the population resides, and three rural districts. The votes of some rural voters weigh almost twice as heavily as do votes in the Reykjavík area, an improvement from earlier times when the ratio was first four and then three, but a ratio of nearly two is still far in excess of the extent of voter inequality tolerated in other countries, such as Norway. As intended, the electoral system has produced a disproportionate representation in parliament of the one third of the electorate living outside Reykjavík. ${ }^{64}$ Thus, the 2013 parliamentary election granted 45 per cent of the seats in parliament to the three rural constituencies where 35 per cent of the voters reside and 55 per cent of the seats to the three urban districts where 65 per cent of the voters reside. To correct this imbalance, the bill proposes 'one person, one vote' - i.e. equal apportionment of seats in parliament - as the fundamental principle behind the electoral system. However, the proposal does not completely abandon the district system as it leaves it to parliament to determine the number of districts anywhere between one and eight. Furthermore, the electoral provision optionally grants voters the right to vote for individuals, even across party lines, rather than for party slates as in the past. The aim here is to widen the selection of candidates available to the voters and to make divisive party primaries unnecessary. In the past, party machines or primaries have essentially doled out safe seats to candidates, leaving next to no room for the voters to influence the outcome. To achieve these ends, the Council arrived at an intricate provision, the original wording of which was found to be a bit complicated, but following their extra meeting in March 2012, councillors were able to reduce the number of words in the provision by a third while keeping its substance intact. ${ }^{65}$

\footnotetext{
${ }^{64}$ T Gylfason, 'From Collapse to Constitution: The Case of Iceland', in L Paganetto (ed.), Public Debt, Global Governance and Economic Dynamism (Springer 2013).

${ }^{65}$ Article 39 'Elections to the Althing', Constitutional Bill for a new constitution for the Republic of Iceland, revised translation of December 11, 2012: "The Althing shall be composed of sixty-three Members, nationally elected by secret ballot for a term of four years. The votes of voters everywhere in the country shall have equal weight. The country may be divided into electoral districts. They shall be eight at the most. Associations of candidates shall put forward slates, either district slates or national slates or both. Candidates may run simultaneously on a national slate and a single district slate of the same association. A voter selects individual candidates from slates in his electoral district or from nationwide slates or both. A voter is also permitted instead to mark a single district slate or a single nationwide slate, in which case the voter will be understood to have selected all the candidates on the slate equally. It is permitted to provide by law that the selection should be limited to the district slate or nationwide slate of the same association. Parliamentary seats shall be allocated to associations of candidates so that the number of Members representing each association is as close in proportion as possible to the total number of votes. The manner of allocating parliamentary seats to candidates based on their strength of vote shall be provided for by law. It is permitted to provide by law that a specified number of parliamentary seats should be tied to individual electoral districts, up to a maximum total of thirty. The number of voters on the electoral register behind each tied seat shall not be lower than the average for all sixty-three seats. The means of promoting as equal a proportion of men and women in the Althing shall be provided for in legislation on elections. Provisions of law relating to electoral district boundaries, the methods of allocating parliamentary seats and rules on candidature can be amended only by a two-thirds majority of the Althing.
} 
Helgason explains the history and intricacies of Iceland's electoral laws. ${ }^{66}$ In view of Iceland's long history of unequal voting rights, the Constitutional Council received, through its digital channels, a relatively large number of proposals focused on equal voting rights from, e.g. Alda - Association for Sustainability and Democracy. ${ }^{67}$

The provisions on freedom of information, ${ }^{68}$ 'without evasion' (or 'without exception' as one English translation reads), ${ }^{69}$ and on natural resources ${ }^{70}$ ( ${ }^{\circ}$ common and perpetual property of the nation') may be linked to the participatory process, too. As was the case with electoral reform, the Council received a number of suggestions concerning those provisions. However, both provisions were in the cards from the beginning, when the contours of the revision took shape. The National Assembly had called for all three in 2010. Also, as Ólafsson has argued, the popular accountability, bestowed on the Council, may have sharpened its emphasis on electoral reform, transparency, national ownership of natural resources, and also environmental protection. ${ }^{71}$

The fact that several provisions in the proposal were quite long and detailed, including the ones on elections, transparency, natural resources, and the environment, was perhaps not directly influenced by external input into the Council's work. Rather, the reason for the length and detail was the perception of the Council that in some cases legislation is not enough, especially in areas where laws have been perceived as lagging behind. In such cases, the constitution makers may see fit to mend certain gaps in the constitution as was pointed out,

\footnotetext{
Amendments of this kind may not be made when there are less than six months until the next election and their entry into force shall be postponed if an election is called within six months from their confirmation."

${ }^{66}$ T Helgason, 'Improvements in the Apportionment of Parliamentary Seats in Iceland' (2014) 10(2) Icelandic Review of Politics and Administration, 1.

${ }^{67}$ See the proposals received from Alda here: $<$ http://en.alda.is/?p=68>.

${ }^{68}$ Article 15 on Freedom of Information reads "Information and documents in the possession of the government shall be available without evasion and the law shall ensure public access to all documents collected or procured by public entities. A list of all cases and documents in public custody, their origin and content shall be available to all."

${ }^{69}$ ACM Meuwese, 'Popular constitution-making. The case of Iceland', in D Galligan and M Versteeg (eds.), The social and political foundations of constitutions (Cambridge University Press 2013).

70 The proposal for Article 34 on Natural Resources reads "Iceland's natural resources which are not in private ownership are the common and perpetual property of the nation. No one may acquire the natural resources or their attached rights for ownership or permanent use, and they may never be sold or mortgaged. Resources under national ownership include resources such as harvestable fish stocks, other resources of the sea and sea bed within Icelandic jurisdiction and sources of water rights and power development rights, geothermal energy and mining rights. National ownership of resources below a certain depth from the surface of the earth may be provided for by law. The utilization of the resources shall be guided by sustainable development and the public interest. Government authorities, together with those who utilize the resources, are responsible for their protection. On the basis of law, government authorities my grant permits for the use or utilization of resources or other limited public goods against full consideration and for a reasonable period of time. Such permits shall be granted on a non-discriminatory basis and shall never entail ownership or irrevocable control of the resources." ${ }^{71}$ J Ólafsson, 'An Experiment in Iceland: Crowdsourcing a Constitution?' (2012) Working Paper, $<$ www.yale.edu/polisci/conferences/epistemic_democracy/jOlafsson.pdf > accessed 11 March 2016.
} 
for example, by an official at Europol in Rotterdam. He wrote the Constitutional Council to argue that Icelandic legislation concerning the confiscation of stolen property lags behind that of many other European nations and suggested that the Council include a provision on such confiscation in its bill. This advice was discussed, but not heeded; however, it provides an illustration of the type of reasoning that led to rather lengthy provisions in some cases. Another example is that parliament's slow legislative action to equalize voting rights prompted the inclusion of detailed electoral rules in the constitutional bill.

\section{E. Link with the outcome?}

Based on data from developing countries in transition, Moehler suggests that rather than direct participation, it is the involvement of local leaders that leads citizens to support a new constitution. ${ }^{72}$ According to Klein and Sajó, 'even where participation has created constitutional enthusiasm this may not result in lasting or widespread acceptance of the constitution, especially where high expectations of empowerment do not materialize' ${ }^{73}$

These hypotheses appear to contradict the Icelandic experience. In Iceland, it seems most plausible that the overwhelming 'yes' vote in the 2012 referendum reflected a widespread sense of ownership. This may well have been triggered by the open invitation to the public and the resulting engagement of the many citizens who in 2010 were candidates in the Constitutional Assembly election or attended the National Assembly. It is also possible, however, that popular participation had no significant effect on the results of the referendum. This can be argued on the grounds that the outcome of the referendum - 67 per cent in favour, 33 per cent against - reflected the division between supporters and opponents in parliament. The parliament's Constitutional and Supervisory Committee during 2009-2013 was split: six in favour of the bill vs. three against. Furthermore, when parliament voted on whether to hold the 2012 referendum, 67 per cent of MPs voted in favour and 33 per cent against, not counting absentees. It seems likely that, had the bill been brought to a vote in parliament in 2013, it would have passed two to one, with several abstentions. It is, therefore, tempting to conclude that this is why the speaker of parliament did not call a vote.

Turning against the bill after the referendum, some academics expressed the sentiment that the Council had encroached on their turf. For example, after the referendum, a professor of political science who had kept silent throughout the process said in a newspaper interview

\footnotetext{
72 D Moehler, Distrusting Democrats: Outcomes of Participatory Constitution-Making (University of Michigan Press 2006).

${ }^{73}$ C Klein and A Sajó, 'Constitution-Making: Process and Substance' in M Rosenfeld and A Sajó (eds.), Oxford Handbook of Comparative Constitutional Law (Oxford University Press 2012), 412.
} 
that the Council was 'completely illegitimate', adding that 'a certain elite' (presumably including himself) should rewrite the constitution. ${ }^{74}$ However, as the overview of the use of digital tools above demonstrates, no one could justifiably complain that he or she did not have access to the process.

\section{Conclusion: Bittersweet lessons from a unique experiment}

One of us has argued elsewhere that the impromptu character of the procedure and a lack of constraints on the sources of 'constitutional input', compounded by a few of the more radical provisions proposed, were the cause of the constitutional bill's derailment in parliament. ${ }^{75}$ Others have argued that concessions to parliament through a less ambitious bill - say, one without equal voting rights and without public ownership of natural resources would not have reflected the conclusion of the National Assembly. The reasoning is that such a bill would not have been passed unanimously in the Council if at all, and would not have won approval in the national referendum. ${ }^{76}$ Under normal circumstances, perhaps, concessions to the parliament and to special interests along these lines might have been advisable and justifiable, but less than three years after Iceland's spectacular financial crash, ${ }^{77}$ with parliament's reputation in shatters, such concessions found little support. Even at the time of writing, nearly seven years after the crash, parliament enjoys the trust of 14 to 18 per cent of Icelandic respondents in public opinion polls, which is barely more than the banks. ${ }^{78}$

This chapter has revolved around the use of digital online tools to aid the drafting and its meaning for the identification "We the people". What lessons can be drawn, specifically in relation to the knowledge of today regarding the outcome?

Delivering its bill to parliament, the Council wrote in its cover letter that " $[\mathrm{t}]$ he idea that the public had their say in the revision of the constitution has [...] been preserved"79. Technology

\footnotetext{
74 T Gylfason, 'Constitution on Ice', (2014) CESifo Working Paper No. 5056, forthcoming in Ingimundarson et al. (eds.) Iceland's Financial Crisis: The Politics of Blame, Protest, and Reconstruction (Routledge 2016)

${ }^{75}$ ACM Meuwese, 'Popular constitution-making. The case of Iceland', in D Galligan and M Versteeg (eds.), The social and political foundations of constitutions (Cambridge University Press 2013).

${ }^{76}$ T Gylfason, 'From Collapse to Constitution: The Case of Iceland', in L Paganetto (ed.), Public Debt, Global Governance and Economic Dynamism (Springer 2013); T Gylfason, 'Constitution on Ice', (2014) CESifo Working Paper No. 5056, forthcoming in Ingimundarson et al. (eds.) Iceland's Financial Crisis: The Politics of Blame, Protest, and Reconstruction (Routledge 2016).

${ }^{77}$ L Laeven and F Valencia, 'Systemic Banking Crises Data Base: An Update' (2012) IMF Working Paper $\mathrm{WP} / 12 / 163$

${ }^{78}$ See <http://mmr.is/frettir/birtar-nieurstoeeur/507-bankakerfidh-og-fjarmalaeftirlitidh-medh-minnsta-traustidhaf-helstu-stofnunum-landsins $>$ and $<$ https://datamarket.com/data/set/1wb6/traust-til-stofnana-skv-thjodarpulsicapacent $\# ! \mathrm{ds}=1 \mathrm{wb} 6 ! 1 \mathrm{xyh}=1 \&$ display=line $>$ accessed 11 March 2016 . These surveys were taken before Iceland surfaced at the center of the Panama Papers scandal in early 2016.

${ }^{79}$ ACM Meuwese, 'Popular constitution-making. The case of Iceland', in D Galligan and M Versteeg (eds.), The social and political foundations of constitutions (Cambridge University Press 2013).
} 
alone does not guarantee popular participation. The infamous case of the Hungarian politician - involved in the recent unusually fast and closed process of constitution-making in Hungary - who declared that the constitution was written on his iPad, ${ }^{80}$ would not have gone down well in Iceland. Even ICT structures specifically designed to facilitate popular involvement do not guarantee success. Technology is not a substitute for democracy, even if technology can be a catalyst of democracy. Iceland went far beyond technology, using state-of-the-art methods of communication to harness the collective intelligence of the people, hundreds of them. This makes parliament's hijacking of the process all the more regrettable.

Even if the experiment has not yet brought Iceland a new constitution, can the outside world benefit from the experience? The Icelandic exercise has shown that, as highlighted in this chapter, high-quality input into constitution-making processes through digital participation is possible. Broadening the debate to include participants from outside the nation state concerned, and thereby to issues beyond the programmatic radar of political parties, puts the onus on the political establishment to defend the status quo with substantive arguments. However, as the Icelandic experience also shows, this very dynamic makes trumping substance by process an attractive option for incumbent political representatives. This means that procedures need some extra attention before starting. However, this does not diminish the one lesson the world can take away from the Icelandic constitution-writing effort, 'crowdsourced' to a significant extent. Other countries can also harness the collective intelligence of the people through scaling-up, using digital tools in combination with statistical sampling techniques to ensure that the input considered by the drafters reflects the much larger input received, with or without the intermediate step of a National Assembly.

\footnotetext{
${ }^{80}$ M Claes, 'The Changing Rules of Constitutional Change' in Jan - Herman Reestman and others (eds.), De Regels en het Spel, Opstellen over Recht, Filosofie, Literatuur en Geschiedenis aangeboden aan Tom Eijsbouts (T.M.C. Asser Press 2011), 103.
} 


\section{References}

Árnason ÁT, 'A Review of the Icelandic Constitution - Popular Sovereignty or Political Confusion' [2011] Tijdschrift voor Constitutioneel Recht, 342

Bater R, 'Hope from Below: Composing the Commons in Iceland' (2011)

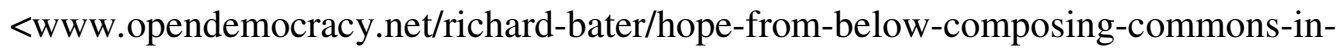
iceland $>$

Claes M, 'The Changing Rules of Constitutional Change' in Jan - Herman Reestman and others (eds.), De Regels en het Spel, Opstellen over Recht, Filosofie, Literatuur en Geschiedenis aangeboden aan Tom Eijsbouts (T.M.C. Asser Press 2011)

Elkins Z, Ginsburg T and Melton J, ‘A Review of Iceland's Draft Constitution', (2012) $<$ http://comparativeconstitutionsproject.org/wp-content/uploads/CCP-Iceland-Report.pdf> accessed 26 January 2016

Elster J, 'Icelandic Constitution-making in Comparative Perspective', in Ingimundarson et al. (eds.) Iceland's Financial Crisis: The Politics of Blame, Protest, and Reconstruction (Routledge 2016)

Gylfason T, 'Crowds and Constitutions', (13 October 2011) <voxeu.org/article/crowds-andconstitutions-insights-iceland>

Gylfason T, 'Constitutions: Financial Crisis Can Lead to Change' (2012) 55(5) Challenge 346

Gylfason T, 'From Collapse to Constitution: The Case of Iceland', in L Paganetto (ed.), Public Debt, Global Governance and Economic Dynamism (Springer 2013)

Gylfason T, 'Constitution on Ice', (2014) CESifo Working Paper No. 5056. Forthcoming in Ingimundarson et al. (eds.) Iceland's Financial Crisis: The Politics of Blame, Protest, and Reconstruction (Routledge 2016)

Gylfason T, 'Tvöfalt líf: Porvaldur Gylfason ræðir við Práin Bertelsson (Double Life: Thorvaldur Gylfason Interviews Thráinn Bertelsson)’ (2014) 4 Tímarit Máls og menningar (Journal of Language and Culture) 1-31

Gylfason T, 'Iceland: How Could This Happen?' in TM Andersen, M Bergman and SE Hougaard Jensen (eds.), Reform Capacity and Macroeconomic Performance in the Nordic Countries (Oxford University Press 2015)

Helgason T, 'Greining á úrslitum kosningar til stjórnlagapings 27. nóvember 2010 (Analysis of the results of the Constitutional Assembly election November 27 2010)' (2011) 7(1) Icelandic Review of Politics and Administration 40

Helgason T, 'Improvements in the Apportionment of Parliamentary Seats in Iceland' (2014) 10(2) Icelandic Review of Politics and Administration 1 
House of Commons, Corrected transcript of oral evidence taken before the Political and Constitutional Reform Committee, 'Mapping the Path to Codifying - or not Codifying the UK's Constitution', Questions to Professor Guðmundur Hálfdánarson, (July 14 2011), HC 1178-ii

Ingimundarson V, Urfalino P and Erlingsdóttir I (eds.), Iceland's Financial Crisis: The Politics of Blame, Protest, and Reconstruction (Routledge 2016)

Klein C and Sajó A, 'Constitution-Making: Process and Substance' in Rosenfeld M and Sajó A (eds.), Oxford Handbook of Comparative Constitutional Law (Oxford University Press 2012)

Kristjánsson S, 'Iceland: A Parliamentary Democracy with a Semi-Presidential Constitution' in Ström K, Müller WC, and Bergman T (eds.), Delegation and Accountability in Parliamentary Democracies (Oxford University Press 2003)

Landemore H, 'Inclusive Constitution-Making: The Icelandic Experiment' [2015] vol. 23(2) Journal of Political Philosophy, 166-191

Laeven L and Valencia F, 'Systemic Banking Crises Data Base: An Update' (2012) IMF Working Paper WP/12/163

Levinson S, Our Undemocratic Constitution: Where the Constitution Goes Wrong (and How We the People Can Correct It), (Oxford University Press 2006)

Maier P, Ratification: The People Debate the Constitution, 1787-1788 (Simon and Schuster 2010)

Meuwese ACM, 'Popular constitution-making. The case of Iceland', in Galligan D and Versteeg M (eds), The social and political foundations of constitutions (Cambridge University Press 2013)

Moehler D, Distrusting Democrats: Outcomes of Participatory Constitution-Making (University of Michigan Press 2006)

Ólafsson J, 'An Experiment in Iceland: Crowdsourcing a Constitution?' (2012) Working Paper, <www.yale.edu/polisci/conferences/epistemic_democracy/jOlafsson.pdf> Shirky C, 'The Political Power of Social Media', (2011) 90(1) Foreign Affairs, $<$ https://www.foreignaffairs.com/articles/2010-12-20/political-power-social-media> Special Investigation Commission (SIC), 'Report of the Special Investigation Commission

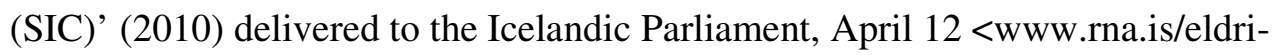
nefndir/addragandi-og-orsakir-falls-islensku-bankanna-2008/skyrslanefndarinnar/english/>

Tryggvadóttir M, Útistöður (Quarrels) (Hansen og synir, Reykjavík, 2014) 
Tushnet M, ‘New Institutional Mechanisms for Making Constitutional Law’ (2015) $<$ http://papers.ssrn.com/sol3/papers.cfm?abstract_id=2589178>

Venice Commission, 'Opinion on the Draft New Constitution of Iceland' (2013) Venice: European Commission for Democracy through Law (Venice Commission), $<$ http://www.althingi.is/pdf/venice.coe.pdf $>$

Widner J, Proceedings 'Workshop on Constitution Building Processes', (2007) Princeton University, May 17-20. Princeton, NJ: Bobst Center for Peace and Justice, Princeton University, Interpeace International IDEA 